\title{
Vibrational Spectra, DFT Calculations, Electronic and Optical Properties of 3-bromo-o-xylene
}

\author{
S. Jeyavijayan, Palani Murugan, M. S. Revathy, S. Kokila, K. Gurushankar
}

\begin{abstract}
The vibrational spectra of 3-bromo-o-xylene have been studied by FTIR and FT-Raman spectra in the regions $4000-400 \mathrm{~cm}^{-1}$ and $3500-50 \mathrm{~cm}^{-1}$, respectively. The geometrical parameters, frequencies and spectral intensities were calculated by density functional theory (DFT/B3LYP) method with $6-31+G(d, p)$ and $6-311++G(d, p)$ basis sets. The experimental and theoretical spectra are compared. The $U V$-Vis spectral analysis and the HOMO-LUMO of the molecule has been calculated which confirms the charge shift of the molecular system. The natural bond orbital investigation has been found for different bonding, antibonding and lone pair interactions and mapped molecular electrostatic potential (MEP) have also been reported.

Index Terms: FTIR, FT-Raman, DFT calculations, 3-bromo-o-xylene, $\mathrm{NBO}$.
\end{abstract}

\section{INTRODUCTION}

Xylene can be found in three forms; meta-xylene (m-xylene), ortho-xylene (o-xylene) and para-xylene (p-xylene), It consists of a benzene ring with two methyl chains and occurs in coal tar, petroleum. It is used as thinners and solvents in paints, varnishes, adhesives and inks. Particularly, o-xylene is used to produce phthalic anhydride, which can be utilizedfor drugs, materials and other chemicals[1]. Xylene is the main precursor to dimethyl terephthalate andterephthalic acids, both of them are used to manufacture polyethylene terephthalate (PET) plastic bottles and polyester clothing[2]. Because of their wide applications, the vibrational, spectral properties of xylene derivatives have been studied by many researchers [3-7]. More recently, Ramalingam et al [8] investigated the vibrational studies on pharmaceutical activity of m-xylene-4-sulphonic acid. In this study, the compound 3-bromo-o-xylene (BOX) is effective raw material and mediatorfor many organic synthesis, agrochemicalsand pharmaceuticals. Owing to these industrial importances of xylene and its bromo derivatives, the detailed structural, spectral and DFT computations have been investigated in this study.

Revised Manuscript Received on December 16, 2019

* Correspondence Author

S. Jeyavijayan*, Department of Physics, Kalasalingam Academy of Research and Education, Krishnankoil-626 126, Tamil Nadu, India Email : sjeyavijayan@gmail.com

Palani Murugan, Department of Physics, Dr. B.R. Ambedkar Institute of Technology, Port Blair-744103, Andaman \& Nicobar Islands, India Email : palanimuruganviji@gmail.com

M.S.Revathy, Department of Physics, Kalasalingam Academy of Research and Education, Krishnankoil-626 126,Tamil Nadu, India Email : revz.vijay@gmail.com

S.Kokila, Department of Physics, Kalasalingam Academy of Research and Education, Krishnankoil-626 126,Tamil Nadu, India Email : revz.vijay@gmail.com

K. Gurushankar, Department of Physics, Kalasalingam Academy of Research and Education, Krishnankoil-626 126, Tamil Nadu, India Email : kgurumsc@yahoo.com

\section{EXPERIMENTAL}

The FTIR spectra of BOX was recorded in the region $4000-400 \mathrm{~cm}^{-1}$ at a resolution of $\pm 1 \mathrm{~cm}^{-1}$ using Perkin Elmer FTIR spectrometer andthe FT-Raman spectrum of BOX have been recorded in the Stokes region $\left(3500-50 \mathrm{~cm}^{-1}\right)$ on a computer interfaced BRUKER RFS-66V model interferometer operating at $1064 \mathrm{~nm}$ excitation wavelength using Nd:YAG laser. In the quantum chemical calculations, DFT calculations were carried out for BOX with GAUSSIAN 09W program package [9] using the Becke's parameter combined with the Lee-Yang-Parr correlation (B3LYP) functional[10,11] with lower and higher basis sets. The total energy distribution (TED) associated with each vibration is calculated by the MOLVIB program [12]. The electron density(ED) redistribution and hyperconjucative interactions energies have been calculated by natural bond orbital analysis. The UV-Vis and HOMO-LUMO analyses have been computed with same level of calculations to get charge transferinformation of the molecule.

\section{RESULTS AND DISCUSSION}

\section{A. Molecular Geometry}

The molecular structure of BOX is shown in Fig. 1. The most optimized structural parameters calculated by DFT/B3LYP withlower and higher basis sets are compared with X-ray diffraction experimental data [13] and represented in Table I. The optimized structure of BOX indicates that the inclusion of methoxy groups and bromine atom known for their strong electron-donating and electron withdrawing nature, respectively. This is the cause for enlarge in bond length of C3-Br15 (1.921 and $1.932 \AA$ by lower and higher basis sets, respectively). The carbon and hydrogen atoms are bonded with the $\sigma$-bond in benzene. The substitution ofmethoxy groups andbromineatom for hydrogen changes the electron density. From the bond angles given in Table I, the benzene ring seems to be indistinct due to the substituents and is differing from theangle of $120^{\circ}$. For bromine atom, at third position of the benzene ring, the angles $\mathrm{C} 2-\mathrm{C} 3-\mathrm{C} 4$ are found as $122.76^{\circ}$ and the angles $\mathrm{C} 6-\mathrm{C} 1-\mathrm{C} 2, \mathrm{C} 1-\mathrm{C} 2-\mathrm{C} 3$ are calculated as $120.06^{\circ}$ and $117.24^{\circ}$ for methoxy groups at first and second position ofthe benzene ring. 
Vibrational Spectra,DFT Calculations, Electronic and Optical Properties of 3-bromo-o-xylene

Table I. Optimized geometrical parameters of 3-bromo-o-xylene by DFT method

\begin{tabular}{|c|c|c|c|c|c|c|c|}
\hline \multirow{2}{*}{$\begin{array}{c}\text { Bond } \\
\text { Length }\end{array}$} & \multicolumn{2}{|c|}{ Value $(\AA)$} & \multirow[b]{2}{*}{$\operatorname{Expt}^{\mathrm{a}}$} & \multirow{2}{*}{ Bond angle } & \multicolumn{2}{|c|}{ Value $\left({ }^{\circ}\right)$} & \multirow[b]{2}{*}{$\operatorname{Expt}^{\mathrm{a}}$} \\
\hline & $\begin{array}{c}\text { B3LYP/6-31+G( } \\
\text { d,p) }\end{array}$ & $\begin{array}{c}\text { B3LYP/6-311+ } \\
+\mathrm{G}(\mathrm{d}, \mathrm{p})\end{array}$ & & & $\begin{array}{c}\text { B3LYP/6-31+ } \\
\text { G(d,p) }\end{array}$ & $\begin{array}{c}\text { B3LYP/6-311++G( } \\
\text { d,p) }\end{array}$ & \\
\hline $\mathrm{C} 1-\mathrm{C} 2$ & 1.418 & 1.415 & 1.393 & C2-C1-C6 & 120.05 & 120.06 & 119.5 \\
\hline $\mathrm{C} 1-\mathrm{C} 6$ & 1.398 & 1.395 & 1.401 & $\mathrm{C} 2-\mathrm{C} 1-\mathrm{C} 7$ & 120.36 & 120.25 & 120.4 \\
\hline $\mathrm{C} 1-\mathrm{C} 7$ & 1.511 & 1.510 & 1.496 & $\mathrm{C} 6-\mathrm{C} 1-\mathrm{C} 7$ & 119.60 & 119.69 & 117.6 \\
\hline $\mathrm{C} 2-\mathrm{C} 3$ & 1.402 & 1.400 & 1.377 & $\mathrm{C} 1-\mathrm{C} 2-\mathrm{C} 3$ & 117.39 & 117.24 & 119.0 \\
\hline $\mathrm{C} 2-\mathrm{C} 11$ & 1.509 & 1.508 & 1.508 & $\mathrm{C} 1-\mathrm{C} 2-\mathrm{C} 11$ & 119.35 & 119.39 & 119.5 \\
\hline C3-C4 & 1.396 & 1.393 & 1.371 & C3-C2-C11 & 123.26 & 123.37 & 121.5 \\
\hline $\mathrm{C} 3-\mathrm{Br} 15$ & 1.921 & 1.932 & 1.896 & $\mathrm{C} 2-\mathrm{C} 3-\mathrm{C} 4$ & 122.60 & 122.76 & 122.6 \\
\hline $\mathrm{C} 4-\mathrm{C} 5$ & 1.392 & 1.389 & 1.380 & $\mathrm{C} 2-\mathrm{C} 3-\mathrm{Br} 15$ & 120.97 & 121.19 & 121.2 \\
\hline C4-H16 & 1.084 & 1.082 & 0.930 & $\mathrm{C} 4-\mathrm{C} 3-\mathrm{Br} 15$ & 116.44 & 116.04 & 116.2 \\
\hline $\mathrm{C} 5-\mathrm{C} 6$ & 1.395 & 1.392 & 1.352 & $\mathrm{C} 3-\mathrm{C} 4-\mathrm{C} 5$ & 119.15 & 119.02 & 119.1 \\
\hline C5-H17 & 1.086 & 1.084 & 0.930 & C3-C4-H16 & 120.01 & 120.08 & 122.8 \\
\hline C6-H18 & 1.087 & 1.085 & 0.930 & C5-C4-H16 & 120.84 & 120.90 & 119.5 \\
\hline $\mathrm{C} 7-\mathrm{H} 8$ & 1.097 & 1.095 & 0.960 & C4-C5-C6 & 119.69 & 119.75 & 120.0 \\
\hline C7-H9 & 1.097 & 1.095 & 0.960 & C4-C5-H17 & 119.84 & 119.81 & 120.0 \\
\hline C7-H10 & 1.093 & 1.091 & 0.960 & C6-C5-H17 & 120.47 & 120.44 & 120.0 \\
\hline C11-H12 & 1.097 & 1.095 & 0.960 & C1-C6-C5 & 121.13 & 121.17 & 121.6 \\
\hline C11-H13 & 1.097 & 1.095 & 0.960 & C1-C6-H18 & 119.16 & 119.14 & 121.6 \\
\hline \multirow[t]{13}{*}{ C11-H14 } & 1.089 & 1.087 & 0.960 & C5-C6-H18 & 119.71 & 119.69 & 123.2 \\
\hline & & & & C1-C7-H8 & 111.75 & 111.68 & 109.5 \\
\hline & & & & C1-C7-H9 & 111.74 & 111.68 & 109.5 \\
\hline & & & & $\mathrm{C} 1-\mathrm{C} 7-\mathrm{H} 10$ & 110.82 & 110.77 & 109.5 \\
\hline & & & & H8-C7-H9 & 106.77 & 106.81 & 109.5 \\
\hline & & & & $\mathrm{H} 8-\mathrm{C} 7-\mathrm{H} 10$ & 107.77 & 107.84 & 109.5 \\
\hline & & & & H9-C7-H10 & 107.77 & 107.84 & 109.5 \\
\hline & & & & $\mathrm{C} 2-\mathrm{C} 11-\mathrm{H} 12$ & 110.99 & 110.90 & 109.5 \\
\hline & & & & C2-C11-H13 & 111.00 & 110.90 & 109.5 \\
\hline & & & & $\mathrm{C} 2-\mathrm{C} 11-\mathrm{H} 14$ & 111.74 & 111.94 & 109.5 \\
\hline & & & & H12-C11-H13 & 106.93 & 106.93 & 109.5 \\
\hline & & & & H12-C11-H14 & 108.00 & 107.99 & 109.5 \\
\hline & & & & H13-C11-H14 & 108.00 & 107.99 & 109.5 \\
\hline
\end{tabular}

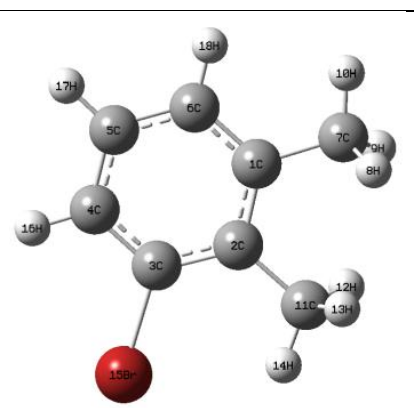

Figure 1. Molecular structure of 3-bromo-o-xylene

\section{B. Thermodynamic Properties}

The thermodynamic parameters of BOX by DFT/B3LYP method are listed in Table II. The global minimum energy obtained for BOX by DFT/B3LYP using 6-31+G(d,p) and $6-311++\mathrm{G}(\mathrm{d}, \mathrm{p})$ basis sets are -2882.0354448 and -2884.5064629 Hartrees, respectively. In this study, the dipolemoment molecule of BOX is found to be 2.0888 and 2.1015 Debye, for lower and higher basis sets, respectively. The thermodynamic data [14]listed in Table II will beuseful to get further information of BOX.

\section{Vibrational Spectra}

The molecule possesses $C_{1}$ point symmetry and contains 18 atoms which give 48 normal vibrations. The observed and computed FTIR and FT-Raman spectra of BOX are represented in Figs. 2 and 3, respectively and thecomplete vibrational assignment of BOXare given in Table III.The calculated frequencies are larger than the experimental onesbecause of the nonharmonic nature and hence it is essential to scale the calculated values by theproper scale factor [15] of 0.96 for B3LYP method.

Table II.The thermodynamic parameters of 3-bromo-o-xylene

\begin{tabular}{|c|c|c|}
\hline \multirow{2}{*}{ Parameters } & \multicolumn{2}{|c|}{ Method/Basis set } \\
\hline & B3LYP/6-31+G(d,p) & B3LYP/6-311++G(d,p) \\
\hline $\begin{array}{l}\text { Optimized global } \\
\text { minimum Energy } \\
\text { (Hartrees) }\end{array}$ & -2882.0354448 & -2884.5064629 \\
\hline $\begin{array}{c}\text { Total } \\
\text { energy(thermal), } \\
\mathrm{E}_{\text {total }}\left(\mathrm{kcal} \mathrm{mol}^{-1}\right)\end{array}$ & 97.886 & 96.083 \\
\hline $\begin{array}{l}\text { Heat capacity, } \mathrm{C}_{\mathrm{v}}(\mathrm{cal} \\
\left.\mathrm{mol}^{-1} \mathrm{k}^{-1}\right) \\
\text { Entropy, } \mathrm{S}\left(\mathrm{cal} \mathrm{mol}^{-1}\right. \\
\left.\mathrm{k}^{-1}\right)\end{array}$ & 32.276 & 31.450 \\
\hline Total & 94.243 & 90.851 \\
\hline Translational & 41.535 & 41.535 \\
\hline Rotational & 30.268 & 30.270 \\
\hline Vibrational & 22.440 & 19.045 \\
\hline $\begin{array}{l}\text { Vibrational energy, } \\
\mathrm{E}_{\mathrm{vib}}\left(\mathrm{kcal} \mathrm{mol}^{-1}\right)\end{array}$ & 96.108 & 94.305 \\
\hline $\begin{array}{l}\text { Zero point } \\
\text { vibrational energy, } \\
\left(\mathrm{kcal} \mathrm{mol}^{-1}\right)\end{array}$ & 92.3689 & 90.8842 \\
\hline $\begin{array}{l}\text { Rotational constants } \\
\qquad(\mathrm{GHz})\end{array}$ & & \\
\hline$A$ & 2.1714 & 2.1776 \\
\hline$B$ & 0.7391 & 0.7366 \\
\hline$C$ & 0.5552 & 0.5542 \\
\hline $\begin{array}{l}\text { Dipole moment } \\
\text { (Debye) }\end{array}$ & 2.0888 & 2.1015 \\
\hline
\end{tabular}

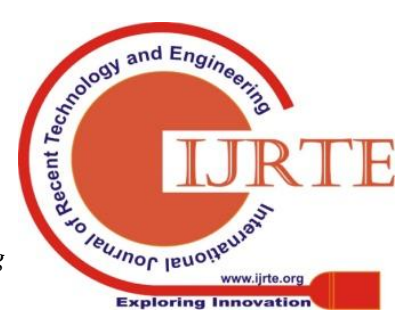




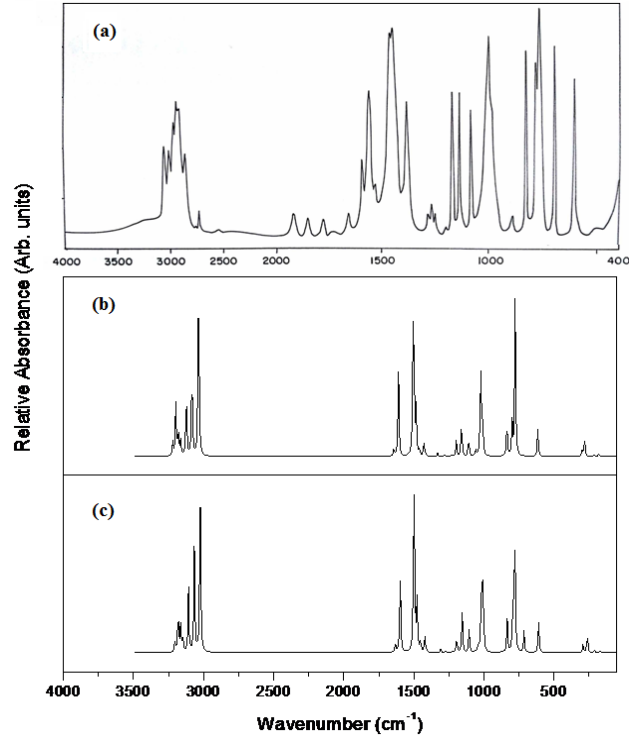

Figure2. FTIR spectra of 3-bromo-o-xylene

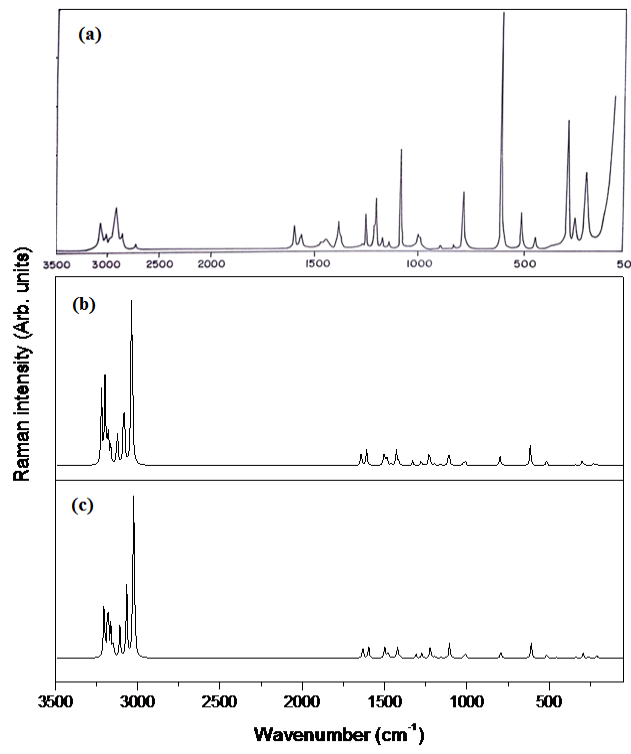

Figure 3. FT-Raman spectra of 3-bromo-o-xylene

\section{C-H Vibrations}

The experimental $\mathrm{C}-\mathrm{H}$ stretching bands appear in the range $3100-3000 \mathrm{~cm}^{-1}$ [16].Hence, the IR frequencies of BOX are assigned at 3102 and $3010 \mathrm{~cm}^{-1}$ for $\mathrm{C}-\mathrm{H}$ stretching modes. The C-H Raman frequencies are observed at 3035 and $3012 \mathrm{~cm}^{-1}$, which are confirmed by the energy distributionaround $100 \%$. The IR band at 1300, 1262, 1200 $\mathrm{cm}^{-1}$ and Raman band at $1260,1202 \mathrm{~cm}^{-1}$ are assigned to $\mathrm{C}-\mathrm{H}$ in-plane vibrations of BOX.

\section{C-C Vibrations}

The spectral range from 1650 to $1400 \mathrm{~cm}^{-1}$ gives rise to the $\mathrm{C}-\mathrm{C}$ aromatic stretching vibrations [17].As a result, the C-C stretching vibrations of BOX are observed at 1640, $1594,1543,1460,1448,1388 \mathrm{~cm}^{-1}$ in FTIR and 1580, 1561, $1450 \mathrm{~cm}^{-1}$ in the FT-Raman spectrum and they are alsoestablished by their TEDcontribution. Also, the bands observed at 790, $684 \mathrm{~cm}^{-1}$ and $782 \mathrm{~cm}^{-1}$ in the FTIR and Raman spectra, respectively, have been assigned to ring in-plane bending modes.

\section{C-Br Vibrations}

Since mixing of vibrations is possible due to the presence of heavy atoms, the vibrations corresponding to $\mathrm{C}-\mathrm{Br}$ bonds arequite interesting [18] and they appear in the lower frequencies i.e. $650-485 \mathrm{~cm}^{-1}$ and their deformation arise in the region $300-140 \mathrm{~cm}^{-1}$. In the present investigation, the band is observed at $750 \mathrm{~cm}^{-1}$ in FTIR spectrum for C-Br stretching vibration. The deformation vibrations of $\mathrm{C}-\mathrm{Br}$ are listed in Table III.

\section{$\mathrm{CH}_{3}$ Group Vibrations}

In the title molecule, there are nine fundamentals associated to each $\mathrm{CH}_{3}$ group. The asymmetric and symmetric modes of $\mathrm{CH}_{3}$ groupis observed around 2980 and $2870 \mathrm{~cm}^{-1}$, respectively $[19,20]$. The IR and Raman spectra of BOX have $\mathrm{CH}_{3}$ out-of-plane stretching bands at 2890, 2730 and 2894, $2732 \mathrm{~cm}^{-1}$, respectively. The $\mathrm{CH}_{3}$ in-plane stretching vibrations are designated at 2962, $2946 \mathrm{~cm}^{-1}$ in IR and 2944 $\mathrm{cm}^{-1}$ in the Raman spectra and they are in excellent conformity with the calculations by B3LYP/6-311++G(d,p) method. The $\mathrm{CH}_{3}$ ss frequencies are established at 3054 and $3065 \mathrm{~cm}^{-1}$ in the FTIR andRaman spectra, respectively, and confirmed with the TED results. The bands at 1240, 1148 and $1242,1150 \mathrm{~cm}^{-1}$ in IR and Raman, respectively, are ascribed to $\mathrm{CH}_{3}$ out-of-plane bending modes of BOX. The bands obtained at $1100 \mathrm{~cm}^{-1}$ in Raman and $1190 \mathrm{~cm}^{-1}$ in both spectra are allocated to $\mathrm{CH}_{3}$ in-plane rocking modes, respectively, and they show reliable conformity with the computed values. The twisting modes and out-of-plane rocking modes of methyl groups are also assigned and given in Table III.

\section{UV-Vis and HOMO-LUMO Analysis}

The molecular orbitals play an significant role in the electric and optical properties and chemical reactions [21,22]. The electronic behavior of BOX have been evaluated byTD-DFT/B3LYP/6-311++G(d,p)calculations in methanol, benzene and chloroform. The wavelengths $(\lambda)$, oscillator strengths $(f)$ and energies for excitation $(E)$ are listed in Table IV and the theoretical ultraviolet spectrum of BOX in different phases is revealed in Fig. 4. From the Frank-Condon principle, the maximum absorption peak $\left(\lambda_{\max }\right)$ in UV-vis spectra correspondthe vertical excitation. The TD-DFT calculations expect three transitions for BOX molecule. The transitions at $5.1879 \mathrm{eV}(238.99 \mathrm{~nm})$ with an oscillator strength $f=0.0003$ is strong in methanol phase. Similarly, transitions found at $5.1783 \mathrm{eV}(239.43 \mathrm{~nm})$ with an oscillator strength $\mathrm{f}=0.0003$ and at $5.1815 \mathrm{eV}(239.28 \mathrm{~nm})$ with an oscillator strength $\mathrm{f}=0.0003$ inbenzene and chloroform, respectively. They are assigned to $\pi \rightarrow \pi^{*}$ transitions and their major contributions were calculated with the help of SWizard program [23]. The absorption wavelength corresponds to the transition from HOMO to LUMO (70\%) and from HOMO-1 to LUMO+2 (97\%) are assigned to $\pi \rightarrow \pi^{*}$ type. The 3D plots of frontier molecular orbitals for BOX are shown in Fig. 5. In $\mathrm{BOX}$, the HOMO is located over ring system, bromine atom and LUMO is delocalized over the $\mathrm{C}-\mathrm{C}$ bond of the ring; hence the $\mathrm{HOMO} \rightarrow$ LUMO transition explains an electron density transfer to the $\mathrm{C}-\mathrm{C}$ bond of the benzene ring and methyl groups from bromine atom, which affects the biological and chemical activity of BOX. 
Vibrational Spectra,DFT Calculations, Electronic and Optical Properties of 3-bromo-o-xylene

Table III. Vibrational assignments of fundamental modes of 3-bromo-o-xylene along with calculated IR intensities and Raman activities based on DFT force field calculation

\begin{tabular}{|c|c|c|c|c|c|c|c|c|c|c|c|}
\hline \multirow{3}{*}{ Sl.No. } & \multirow{2}{*}{\multicolumn{2}{|c|}{$\begin{array}{l}\text { Observed wavenumber } \\
\qquad\left(\mathrm{cm}^{-1}\right)\end{array}$}} & \multicolumn{8}{|c|}{ Calculated frequencies $\left(\mathrm{cm}^{-1}\right)$} & \multirow{3}{*}{$\begin{array}{c}\text { TED\% among } \\
\text { types of } \\
\text { coordinates }\end{array}$} \\
\hline & & & \multicolumn{4}{|c|}{ B3LYP/6-31+G(d,p) } & \multicolumn{4}{|c|}{ B3LYP/6-311++G(d,p) } & \\
\hline & FTIR & $\begin{array}{c}\text { FT } \\
\text { Raman }\end{array}$ & Unscaled & Scaled & $\begin{array}{c}\text { IR } \\
\text { intensity }^{\mathrm{a}}\end{array}$ & $\begin{array}{l}\text { Raman } \\
\text { activity }^{\text {b }}\end{array}$ & Unscaled & Scaled & $\begin{array}{c}\text { IR } \\
\text { intensity }^{\mathrm{a}}\end{array}$ & $\begin{array}{l}\text { Raman } \\
\text { activity }^{\mathrm{b}}\end{array}$ & \\
\hline 1 & 3102(ms) & - & 3220 & 3095 & 4.38 & 134.03 & 3204 & 3080 & 3.43 & 127.71 & $v \mathrm{CH}(98)$ \\
\hline 2 & - & $3065(\mathrm{~s})$ & 3199 & 3075 & 16.10 & 1554.48 & 3181 & 3058 & 14.59 & 156.93 & $\mathrm{CH}_{3 \mathrm{ss}}(92)$ \\
\hline 3 & $3054(w)$ & - & 3180 & 3057 & 8.84 & 74.54 & 3164 & 3042 & 7.75 & 69.50 & $\mathrm{CH}_{3 \mathrm{ss}}(91)$ \\
\hline 4 & - & $3035(\mathrm{vw})$ & 3165 & 3043 & 4.75 & 33.16 & 3147 & 3025 & 4.76 & 32.45 & $v \mathrm{CH}(95)$ \\
\hline 5 & 3010(vw) & $3012(\mathrm{vw})$ & 3124 & 3003 & 19.31 & 68.90 & 3108 & 2988 & 18.81 & 66.24 & $v \mathrm{CH}(94)$ \\
\hline 6 & 2962(w) & - & 3086 & 2967 & 2.43 & 14.14 & 3069 & 2950 & 0.84 & 5.46 & $\mathrm{CH}_{3 \text { ips }}(90)$ \\
\hline 7 & 2946(w) & 2944(s) & 3083 & 2964 & 28.95 & 137.53 & 3067 & 2948 & 30.36 & 148.08 & $\mathrm{CH}_{3 \mathrm{ips}}(89)$ \\
\hline 8 & $2890(\mathrm{~s})$ & 2894(s) & 3038 & 2920 & 29.86 & 207.42 & 3027 & 2910 & 26.82 & 221.57 & $\mathrm{CH}_{3 \text { ops }}(86)$ \\
\hline 9 & $2730(w)$ & 2732(w) & 3034 & 2917 & 27.59 & 173.20 & 3023 & 2906 & 25.56 & 196.12 & $\mathrm{CH}_{3 \mathrm{ops}}(85)$ \\
\hline 10 & $1640(\mathrm{vw})$ & - & 1643 & 1579 & 2.45 & $18 . .2792$ & 1633 & 1570 & 2.67 & 17.91 & $v \mathrm{CC}(85)$ \\
\hline 11 & $1594(\mathrm{~ms})$ & - & 1609 & 1547 & 26.37 & 19.83 & 1598 & 1536 & 25.02 & 19.26 & vCC(84) \\
\hline 12 & - & $1580(\mathrm{~ms})$ & 1506 & 1448 & 18.42 & 6.11 & 1502 & 1444 & 14.94 & 7.00 & vCC(82) \\
\hline 13 & - & 1561(w) & 1504 & 1446 & 16.93 & 5.62 & 1498 & 1440 & 16.91 & 6.99 & vCC(88) \\
\hline 14 & $1543(\mathrm{~ms})$ & - & 1500 & 1442 & 22.47 & 6.80 & 1496 & 1438 & 25.40 & 5.51 & $v \mathrm{CC}(86)$ \\
\hline 15 & - & 1474(vw) & 1486 & 1428 & 0.80 & 11.07 & 1480 & 1423 & 0.68 & 9.14 & $\mathrm{CH}_{3 \mathrm{ipb}}(83)$ \\
\hline 16 & $1460(w)$ & - & 1484 & 1427 & 13.59 & 1.21 & 1477 & 1420 & 14.39 & 1.38 & $v \mathrm{CC}(82)$ \\
\hline 17 & $1448(w)$ & $1450(w)$ & 1460 & 1403 & 1.98 & 2.77 & 1453 & 1397 & 3.54 & 1.91 & vCC(81) \\
\hline 18 & - & $1463(\mathrm{vw})$ & 1429 & 1374 & 4.01 & 18.52 & 1423 & 1368 & 4.91 & 16.46 & $\mathrm{CH}_{3 \mathrm{ipb}}(84)$ \\
\hline 19 & $1388(s)$ & - & 1416 & 1361 & 0.87 & 6.91 & 1411 & 1356 & 0.75 & 4.57 & $v \mathrm{CC}(80)$ \\
\hline 20 & - & $1378(\mathrm{~ms})$ & 1360 & 1307 & 1.22 & 5.57 & 1309 & 1258 & 1.10 & 5.30 & $\mathrm{CH}_{3 \mathrm{sb}}(79)$ \\
\hline 21 & - & $1370(w)$ & 1278 & 1229 & 0.66 & 6.87 & 1273 & 1224 & 0.56 & 6.95 & $\mathrm{CH}_{3 \mathrm{sb}}(78)$ \\
\hline 22 & $1300(\mathrm{vw})$ & - & 1229 & 1181 & 0.70 & 19.96 & 1222 & 1175 & 0.40 & 19.59 & $\mathrm{bCH}(77)$ \\
\hline 23 & $1262(s)$ & $1260(\mathrm{vw})$ & 1216 & 1169 & 0.02 & 0.60 & 1194 & 1148 & 4.47 & 2.19 & bCH(76) \\
\hline 24 & $1240(\mathrm{~s})$ & 1242(s) & 1197 & 1151 & 4.91 & 2.14 & 1135 & 1091 & 11.77 & 1.56 & $\mathrm{CH}_{3 \mathrm{opb}}(75)$ \\
\hline 25 & $1200(\mathrm{vs})$ & $1202(\mathrm{~ms})$ & 1160 & 1115 & 11.22 & 1.87 & 1105 & 1062 & 6.66 & 19.36 & bCH(76) \\
\hline 26 & $1190(v s)$ & 1190(s) & 1109 & 1066 & 6.42 & 19.36 & 1067 & 1026 & 0.21 & 0.26 & $\mathrm{CH}_{3 \text { ipr }}(78)$ \\
\hline 27 & 1148(vs) & $1150(w)$ & 1060 & 1019 & 2.27 & 0.15 & 1040 & 1000 & 2.39 & 0.24 & $\mathrm{CH}_{3 \mathrm{opb}}(72)$ \\
\hline 28 & - & $1100(w)$ & 1023 & 983 & 28.01 & 2.64 & 1018 & 979 & 23.50 & 3.74 & $\mathrm{CH}_{3 \mathrm{ipr}}(74)$ \\
\hline 29 & - & 991(w) & 1011 & 972 & 14.17 & 6.22 & 1006 & 967 & 20.73 & 5.10 & $\mathrm{CH}_{3 \mathrm{opr}}(71)$ \\
\hline 30 & $892(\mathrm{vw})$ & $890(\mathrm{vw})$ & 1004 & 965 & 0.54 & 0.06 & 980 & 942 & 0.15 & 0.00 & $\mathrm{CH}_{3 \text { opr }}(74)$ \\
\hline 31 & $874(\mathrm{vw})$ & - & 956 & 919 & 0.07 & 0.01 & 908 & 873 & 0.00 & 0.17 & $\mathrm{bCC}(72)$ \\
\hline 32 & - & $820(w)$ & 916 & 881 & 0.04 & 0.38 & 834 & 802 & 10.76 & 0.52 & bCC(74) \\
\hline 33 & 790(vs) & - & 836 & 804 & 11.94 & 0.33 & 794 & 763 & 14.55 & 9.46 & Rsymd(70) \\
\hline 34 & - & $782(\mathrm{vs})$ & 799 & 768 & 11.10 & 10.15 & 780 & 750 & 43.14 & 0.24 & Rtrigd(69) \\
\hline 35 & $765(\mathrm{~s})$ & - & 777 & 747 & 48.46 & 0.73 & 714 & 686 & 6.27 & 0.05 & $\omega \mathrm{CH}(65)$ \\
\hline 36 & $750(v s)$ & - & 676 & 650 & 0.17 & 0.35 & 610 & 586 & 9.47 & 19.02 & vCBr(74) \\
\hline 37 & $684(\mathrm{vw})$ & - & 615 & 591 & 8.49 & 5.40 & 525 & 505 & 0.01 & 0.04 & Rasymd(70) \\
\hline 38 & $678(v s)$ & - & 549 & 528 & 0.25 & 0.01 & 516 & 496 & 0.04 & 5.09 & $\omega \mathrm{CH}(68)$ \\
\hline 39 & - & $602(v s)$ & 516 & 496 & 0.05 & 19.82 & 511 & 491 & 0.00 & 0.01 & $\omega \mathrm{CH}(66)$ \\
\hline 40 & 590(vs) & - & 466 & 448 & 0.22 & 0.84 & 457 & 439 & 0.19 & 0.78 & $\omega \mathrm{CC}(67)$ \\
\hline 41 & $550(\mathrm{vw})$ & - & 341 & 328 & 0.23 & 1.15 & 338 & 325 & 0.24 & 1.18 & $\omega \mathrm{CC}(68)$ \\
\hline 42 & - & $510(s)$ & 299 & 287 & 2.05 & 5.11 & 293 & 282 & 2.34 & 5.54 & tRsymd (67) \\
\hline 43 & $502(\mathrm{vw})$ & - & 283 & 272 & 6.60 & 1.39 & 262 & 252 & 6.16 & 1.47 & tRtrigd (69) \\
\hline 44 & - & $450(\mathrm{~ms})$ & 228 & 219 & 0.03 & 2.23 & 212 & 204 & 0.16 & 1.84 & tRasymd (65) \\
\hline 45 & - & $304(v s)$ & 214 & 206 & 0.47 & 1.58 & 211 & 203 & 0.52 & 1.72 & $\mathrm{bCBr}(70)$ \\
\hline 46 & - & $278(\mathrm{~s})$ & 181 & 174 & 0.89 & 0.05 & 171 & 164 & 0.77 & 0.09 & $\omega \mathrm{CBr}(64)$ \\
\hline 47 & - & $270(\mathrm{~s})$ & 123 & 118 & 0.02 & 0.39 & 107 & 103 & 0.02 & 0.54 & $\mathrm{tOCH}_{3}(60)$ \\
\hline 48 & - & 205 (vs) & 52 & 50 & 0.09 & 0.38 & 55 & 53 & 0.08 & 0.52 & $\mathrm{tOCH}_{3}(59)$ \\
\hline
\end{tabular}


Table IV. The calculated absorption wavelength $(\lambda)$, excitation energies (e) and oscillator strengths (f) of

3-bromo-o-xylene calculated by the TD-B3LYP/6-311++g(d,p) method

\begin{tabular}{|c|c|c|c|c|c|c|c|c|c|c|}
\hline \multicolumn{9}{|c|}{ TD-B3LYP/6-311++G(d,p) } & \multirow{3}{*}{ Major Contribution } & \multirow{3}{*}{ Assignment } \\
\hline \multicolumn{3}{|c|}{ Methanol } & \multicolumn{3}{|c|}{ Benzene } & \multicolumn{3}{|c|}{ Chloroform } & & \\
\hline$\lambda(\mathrm{nm})$ & $\mathrm{E}(\mathrm{eV})$ & f & $\begin{array}{c}\lambda \\
(\mathrm{nm})\end{array}$ & $\begin{array}{c}\mathrm{E} \\
(\mathrm{eV})\end{array}$ & f & $\lambda(\mathrm{nm})$ & $\mathrm{E}(\mathrm{eV})$ & $\mathrm{f}$ & & \\
\hline 243.56 & 5.0906 & 0.0002 & $\begin{array}{c}244.5 \\
1\end{array}$ & $\begin{array}{c}5.07 \\
07\end{array}$ & 0.0005 & 244.03 & 5.0807 & 0.0003 & $\mathrm{H} \rightarrow \mathrm{L}(70 \%)$ & $\pi \rightarrow \pi^{*}$ \\
\hline 238.99 & 5.1879 & 0.0003 & $\begin{array}{c}239.4 \\
3\end{array}$ & $\begin{array}{c}5.17 \\
83\end{array}$ & 0.0003 & 239.28 & 5.1815 & 0.0003 & $H \rightarrow L+2(96 \%)$ & $\pi \rightarrow \pi^{*}$ \\
\hline 226.69 & 5.4694 & 0.0002 & $\begin{array}{c}225.0 \\
4 \\
\end{array}$ & $\begin{array}{c}5.50 \\
95 \\
\end{array}$ & 0.0002 & 225.93 & 5.4877 & 0.0002 & $\mathrm{H}-1 \rightarrow \mathrm{L}+2(97 \%)$ & $\pi \rightarrow \pi^{*}$ \\
\hline
\end{tabular}

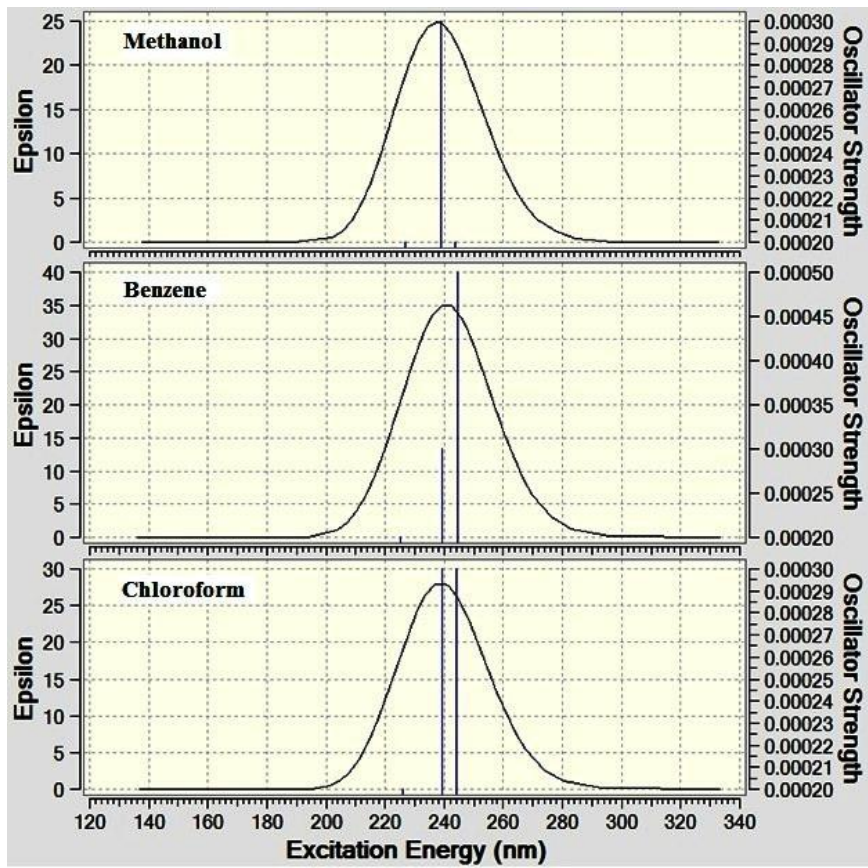

Figure4. Theoretically calculated UV spectrafor 3-bromo-o-xylene

\section{E. NBO Analysis}

From the second-order perturbation approach [24], hyperconjugative interaction energy of BOX was deduced. The donor, acceptor orbitals and their interaction energies for BOX are listed in Table $\mathrm{V}$. The larger the interaction energy $\mathrm{E}(2)$ value shows the stronger interaction between electron-donors and electron-acceptors. The intramolecular interaction of the $\pi$ electrons of $\mathrm{C}-\mathrm{C}$ bonding and antibonding of the ring system gives the stabilization of several portion of the ring. In BOX, the intramolecular hyperconjugative interaction of $\pi(\mathrm{C} 1-\mathrm{C} 6) \rightarrow \pi^{*}(\mathrm{C} 2-\mathrm{C} 3)$ and $\pi(\mathrm{C} 1-\mathrm{C} 6) \rightarrow \pi^{*}$ (C4-C5) leading to stabilization of 20.81 and $21.28 \mathrm{~kJ} / \mathrm{mol}$, respectively. These interactions are found as boost in electron density (ED) of $\mathrm{C}-\mathrm{C}, \mathrm{C}-\mathrm{Br}$ antibonding orbital that affects the respective bonds. The energies for the interaction $\mathrm{n} 3(\mathrm{Br} 15) \rightarrow \pi^{*}(\mathrm{C} 1-\mathrm{C} 6)$ and $\mathrm{n} 2(\mathrm{Br} 15)$ $\rightarrow \pi^{*}(\mathrm{C} 2-\mathrm{C} 3)$ are 9.55 and $3.34 \mathrm{kJmol}^{-1}$ respectively,representsthe interaction between the bromine atom and benzene ring for $\mathrm{BOX}$. There is also a strong interaction from $\pi(\mathrm{C} 2-\mathrm{C} 3) \rightarrow \pi^{*}(\mathrm{C} 4-\mathrm{C} 5)$ that weakens the respective bond $(\mathrm{C} 4-\mathrm{C} 5=1.389 \AA$ by B3LYP/6-311G++(d,p)) with stabilization of $19.88 \mathrm{~kJ} \mathrm{~mol}^{-1}$. The pharmaceuticaland biological properties of BOX mainly depend on these charge transfer interactions.
Table V. Second-order perturbation theory analysis of fock matrix in nbo basis for 3-bromo-o-xylene

\begin{tabular}{|c|c|c|c|c|c|c|}
\hline Donor (i) & $\begin{array}{l}\text { ED } \\
\text { (i) } \\
\text { (e) } \\
\end{array}$ & $\begin{array}{l}\text { Acceptor } \\
\text { (j) }\end{array}$ & $\begin{array}{l}\text { ED } \\
\text { (j) (e) }\end{array}$ & $\begin{array}{c}{ }^{\mathrm{a}} \mathrm{E}(2) \\
(\mathrm{kJ} \\
\left.\mathrm{mol}^{-1}\right) \\
\end{array}$ & $\begin{array}{c}{ }^{\mathrm{b}} \mathrm{E}(\mathrm{j})-\mathrm{E}(\mathrm{i}) \\
\text { (a.u.) }\end{array}$ & $\begin{array}{c}{ }^{{ }^{c} \mathrm{~F}} \\
\text { (i,j) } \\
\text { (a.u.) }\end{array}$ \\
\hline \multirow{2}{*}{$\pi(\mathrm{C} 1-\mathrm{C} 6)$} & \multirow[b]{2}{*}{1.660} & $\pi^{*}(\mathrm{C} 2-\mathrm{C} 3)$ & 0.392 & 20.81 & 0.27 & 0.068 \\
\hline & & $\begin{array}{c}\pi \\
*(\mathrm{C} 4-\mathrm{C} 5)\end{array}$ & 0.328 & 21.28 & 0.28 & 0.069 \\
\hline \multirow[t]{2}{*}{$\pi(\mathrm{C} 2-\mathrm{C} 3)$} & \multirow{2}{*}{1.684} & $\pi^{*}(\mathrm{C} 1-\mathrm{C} 6)$ & 0.335 & 17.81 & 0.30 & 0.066 \\
\hline & & $\pi^{*}(\mathrm{C} 4-\mathrm{C}$ & 0.328 & 19.88 & 0.29 & 0.069 \\
\hline$\pi(\mathrm{C} 4-\mathrm{C} 5)$ & 1.677 & $\begin{array}{l}\pi^{*}(\mathrm{C} 1-\mathrm{C} 6) \\
\pi^{*}(\mathrm{C} 2-\mathrm{C} 3)\end{array}$ & $\begin{array}{l}0.335 \\
0.392\end{array}$ & $\begin{array}{l}18.87 \\
19.67\end{array}$ & $\begin{array}{l}0.29 \\
0.28\end{array}$ & $\begin{array}{l}0.066 \\
0.067\end{array}$ \\
\hline & 1.972 & $\pi^{*}(\mathrm{C} 2-\mathrm{C}$ & 0.392 & 3.34 & 0.86 & 0.048 \\
\hline $\mathrm{n} 3(\mathrm{Br} 15)$ & 1.941 & $\pi *(\mathrm{C} 1-\mathrm{C} 6)$ & 0.335 & 9.55 & 0.31 & 0.053 \\
\hline
\end{tabular}

${ }^{\mathrm{a}} \mathrm{E}(2)$ means energy of hyperconjugative interactions.

${ }^{\mathrm{b}}$ Energy difference between donor and acceptor $\mathrm{i}$ and $\mathrm{j}$ NBO orbitals.

${ }^{\mathrm{c}} \mathrm{F}(\mathrm{i}, \mathrm{j})$ is the Fock matrix element between $\mathrm{i}$ and $\mathrm{j}$ NBO orbitals.
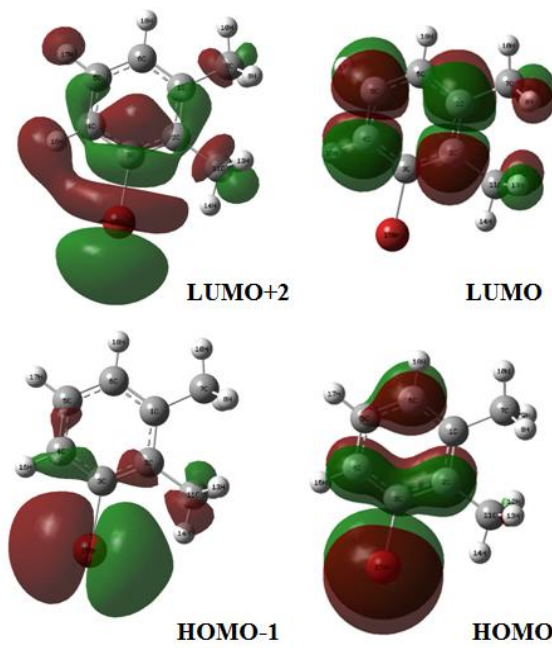

LUMO

(First Excited State)

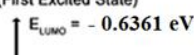

Figure 5.Frontier molecular orbital for

3-bromo-o-xylene

\section{F. Electrostatic Potential, Total Electron Density and} Molecular Electrostatic Potential

The electrophilic and nucleophilic attack [25] for BOX can be predicted from the MEP analysis by B3LYP/6-311++G(d,p) method and the pictorial representation is given in Fig. 6. Here,the negative ESP is distributed over the benzene ring, bromine atom and is reflected as a yellowish blob, the positive ESP is contained on the rest of the molecule. The potential energy increases from red < orange < yellow < green < blue in the MEP figure. In the present study, the MEP map indicates that the negative potential sites are on bromine atom (Red) and the positive potential sites are around the hydrogen atoms of the molecule (Blue). In BOX, the

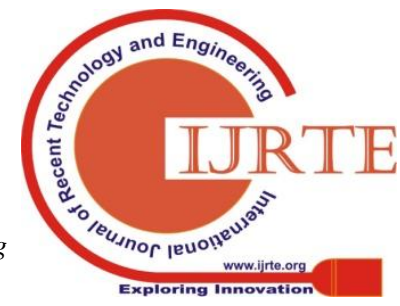


$\mathrm{H}$ atoms indicate the strongest attraction and bromine atom indicate the strongest repulsion.

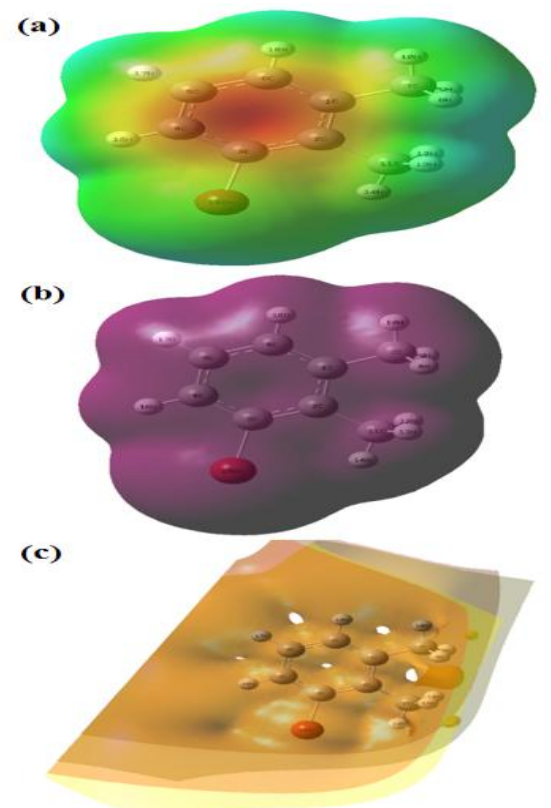

Figure 6.(a) Electrostatic potential (ESP); (b) electron density (ED) and (c) the molecular electrostatic potential (MEP) map for 3-bromo-o-xylene

\section{CONCLUSION}

The optimized parameters andcomplete vibrational bands of 3-bromo-o-xylene have been determined using DFT-B3LYP method. The frequency assignment for normal modes is supported by the TED calculation. The NBO analysis explains the hyper conjugative interaction of BOX.The MEP surface drawn and decrease in HOMO-LUMO gap may lead to the understanding of electronic properties and chemical activity of the molecule. The theoretical UV-vis spectrum supports the energy gap of the molecule. These results will be evidence for 3-bromo-o-xylene in pharmaceuticals,reaction intermediates and polymer science.

\section{REFERENCES}

1. J. Fabri, U.Graeser, and T.A.Simo, "Xylenes". Ullmann's Encyclopedia of Industrial Chemistry," Wiley-VCH, Weinheim, 2000.

2. R.A.F.Tomás, J.C.M.Bordado, andJ.F.P. Gomes,"p-Xylene oxidation to terephthalic acid: a literature review oriented toward process optimization and development," Chem. Rev.2 vol. 113(10), 2013, pp. 7421-7469.

3. V.Arjunan, P.S.Balamourougane, I.Saravanan, and S.Mohan,"Investigation of the structural and harmonic vibrational properties of 2-nitro-, 4-nitro- and 5-nitro-m-xylene by ab initio and density functional theory,"Spectrochim. Acta A Mol. Biomol. Spectrosc., vol. 74, 2009, pp. 798-807.

4. M.Govindarajan, andM. Karabacak,"Analysis of vibrational spectra (FT-IR and FT-Raman) and nonlinear optical properties of organic 2-chloro-p-xylene,"Spectrochim. Acta A Mol. Biomol. Spectrosc., vol. 94, 2012, pp. 36-47,.

5. M.Arivazhagan,and R.Meenakshi, "Vibrational spectroscopic studies and DFT calculations of 4-bromo-o-xylene,"Spectrochim. Acta A Mol. Biomol. Spectrosc., vol 91,2012, pp. 419-430.

6. M.Manzoor ali, G.George,S. Ramalingam,S. Periandy, and V. J. Gokulakrishnan, "Spectroscopic investigation and chemical properties computational analysis,"J. Mol. Struct., vol. 1106,2016, pp. 37-52.

7. G.Venkatesh,M. Govindaraju, C. Kamal, P. Vennila,and S.Kaya, "Structural, electronic and optical properties of 2,5-dichloro-p-xylene: experimental and theoretical calculations using DFT method,"RSC Adv.,vol. 7,2017, pp. 1401-1412. analysis on anticancer compound; $\alpha, \alpha, \dot{\alpha}, \dot{\alpha}-$ Tetrabromo-p-Xylene with

8. S.Ramalingam,M. Manzoor Ali,G. George, A.A.Manthiri, and S.Periandy, "Vibrational investigation on pharmaceutical activity of m-xylene-4-sulphonic acid by quantum computational and experimental support,"J. Taibah Univ. Sci., vol. 12(1),2018, pp. 87-103.

9. H.J. Frisch, G.W. Trucks, H.B. Schlegel, G.E. Scuseria, M.A. Robb, J.R. Cheeseman, H.Nakatsuji, M. Caricato, X. Li, H.P. Hratchian, K. Toyota, R. Fukuda, J.Hasegawa, M. Ishida, R. Nakajima, Y. Honda, O. Kilao, H. Nakai, T. Verven, J. A. Montgomery Jr., J.E. Peralta, F. Ogliaro, M. Bearpark, J. J. Heyd, E. Brothers, K. N. Kudin, V.N. Staroveror, R. Kobayashi, J. Normand, K. Ragavachari, A. Rendell, J.C. Burant, S. J. Tomasi, M. Cossi, N. Rega, J. M. Millam, M. Klene, J. E. Knox, J. B. Cross, V. Bakken, C. Adamo, J. Jaramillo, R. Gomperts, R.E. Strattmann, O. Yazyev, A.J. Austin, R. Cammi, J.W Ochetrski, R.L. Martin, K. Morokuma, V.G. Zakrazawski, G.A.Votn, P. Salvador, J.J. Dannenberg, S. Dapprich, A.D. Daniels, O. Farkas and J.B. Foresman, Gaussian O.G., Revision A.O2, Gaussian Inc., Wallingford, CT. 2009.

10. A.D. Becke,"Density-functional thermochemistry. III. The role of exact exchange,"J. Chem. Phys., vol. 98, 1993, pp. 5648-5652.

11. C.Lee, W.Yang, and R.R. Parr, "Development of the Colic-Salvetti correlation-energy formula into a functional of the electron density,"Phys. Rev. B., vol.37, 1988, pp. 785-789.

12. MOLVIB (V.7.0): Calculation of Harmonic Force Fields and Vibrational Modes of Molecules, QCPE Program No. 807, 2002.

13. S.Dai, and Y.Wang,Crystal structure 1-bromo-4-methanesulfonyl-2,3-dimethylbenzene,Acta Cryst.,vol. E71,2015, pp. o973,

14. R. Zhang, B. Du, G. Sun, and Y. Sun, "Experimental and theoretical studies on o-, m- and p-chlorobenzylideneaminoantipyrines,"Spectrochim. Acta A Mol. Biomol. Spectrosc., vol.75, 2010, pp.1115-1124.

15. D.C.Young, Computational Chemistry: A Practical Guide for Applying Techniques to Real World Problems (Electronic), 2001, John Wiley \& Sons Ltd., New York.

16. E. Gobinath, S. Jeyavijayan, and R. John Xavier, "Spectroscopic investigations, DFT computations and other molecular properties of 2,4-dimethylbenzoic acid,"Indian J. Pure \& Appl. Phys., vol.55, 2017, pp.541-550.

17. S. Jeyavijayan, "Molecular structure, vibrational spectra, NBO analysis, first hyperpolarizability, and HOMO-LUMO studies of 2-amino-4-hydroxypyrimidine by density functional method,"J. Mol. Struct., vol. 1085, 2015, pp.137-146.

18. Socrates G. Infrared and Raman Characteristic Group Frequencies Tables and Charts, 2001, third ed., Wiley, Chichester,

19. S.Ramalingam,S. Periandy,B. Narayanan,and S.Mohan,"FTIR and FTRaman spectroscopic investigation of 2-bromo-4-methylaniline using ab initio HF and DFT calculations,"Spectrochim. Acta A Mol. Biomol. Spectrosc., 2010, vol. 76(1), pp. 84-92.

20. N. Y.SugirthaSuni,L. GuruPrasad,and R.GanapathiRaman Rajendran,"Vibrational Analysis and Non Linear Optical Activity of 3-fluoro-4-methylbenzonitrile,’Orient. J. Chem., vol.34(3),2018, pp. 1638-1645.

21. I.Fleming, Frontier Orbitals and Organic Chemical Reactions, 1976, Wiley, London.

22. S. Jeyavijayan, "Molecular structure, spectroscopic (FTIR, FT-Raman, $13 \mathrm{C}$ and $1 \mathrm{H}$ NMR, UV), polarizability and first-order hyperpolarizability, HOMO-LUMO analysis of 2,4-difluoroacetophenone,"Spectrochim. Acta A Mol. Biomol. Spectrosc., vol. 136, 2015, pp. 553-566,

23. S.I.Gorelsky, SWizard Program Revision 4.5, 2010, University of Ottawa, Ottawa, Canada.

24. J. Choo, S. Kim, H. Joo, and Y. Kwon, "Molecular structures of (trifluoromethyl)iodine dihalides CF3IX2 (X=F, Cl): ab initio and DFT calculations,"J. Mol. Struct. (Theochem.), vol. 587, 2002, pp. 1-8.

25. J.S.Murray,and K. Sen,"Molecular Electrostatic Potentials, Concepts and Applications,"Elsevier, Amsterdam, 1996, pp. 7-624.

\section{AUTHORS PROFILE}

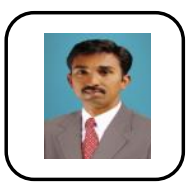

S. Jeyavijayan has completed M.Sc. and Ph.D. from Bharathidasan University, Trichirappalli in 2014.Currently working as Assistant Professor in the Department of Physics, Kalasalingam Academy of Research and Educationand published more than 25 papers in National and International Journals. His fields of interest are Molecular Spectroscopy and Theoretical and Computational chemistry. 


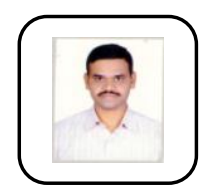

Palani Murugan has completed M.Sc from Bharathiar University, Coimbatore and M.Phil from Bharathidasan University, Tiruchirapalli. Presently working as Lecturer, Physics, in DR.B.R.Ambedkar Institute of Technology Port Blair since June 2012. Currently pursuing Ph.D from Kalasalingam Academy of Research and Education.

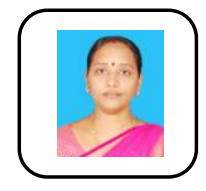

M.S.Revathy, has completed her Ph.D in Anna University in 2016. She has done M.Sc., M.Phil Physics in Mother Teresa Women's University, Kodaikanal. Currently working as Assistant Professor in Department of Physics, Kalasalingam Academy of Research and Education and her field of interests are thin films and green synthesis of nanomaterials. She has published 6 papers in national and international journals.

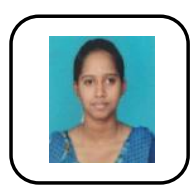

S.Kokilais currently pursuing undergraduation in Physics

in Kalasalingam Academy of Research and Education.

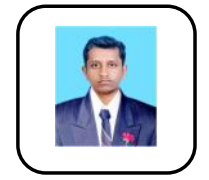

K. Gurushankar has completed M.Sc. and M.Phil., Ph.D. from Annamalai University Chidambaram in 2015. Joined as Assistant Professor at Kalasalingam University from June 2016 onwards. His fields of interest are "Applied spectroscopy in biological field". He has published 12 papers in leading International Journals. 